\title{
Protein supplementation in strength and conditioning adepts: knowledge, dietary behavior and practice in Palermo, Italy
}

\author{
Antonino Bianco ${ }^{1,4^{*}}$, Caterina Mammina ${ }^{2}$, Antonio Paoli ${ }^{3}$, Marianna Bellafiore ${ }^{1}$, Giuseppe Battaglia ${ }^{4}$,
} Giovanni Caramazza ${ }^{4}$, Antonio Palma ${ }^{1,4}$ and Monèm Jemni ${ }^{5}$

\begin{abstract}
Background: It is known that supplement use is a widespread and accepted practice by athletes and people who attend commercial gyms. Little is known about protein supplement amongst people undertaking strength training in commercial gyms in Italy when compared to the US.
\end{abstract}

Objective: The purpose of this study was to examine the use of protein supplementation, alone or in association with other supplements, and dietary behavior amongst regular fitness center attendees in Palermo, Italy.

Design: Resistance training information have been collected from 800 regular fitness center attendees for the initial analysis. A specific questionnaire was generated for the experimentation. Data were collected using a face-toface interview method. Supplement users were then compared to the non users and analyzed using a one-way ANOVA, Kruskall-Wallis, chi-square test or exact test of Fisher when appropriate.

Results: $30.1 \%$ of the respondents use dietary supplements during their training as a believe it is the "way to gain muscles and strength". Whey protein shakes (50.0\%) mixed with creatine and amino-acids (48.3\%) were the most frequent choices amongst the users. A majority of the subjects (34.0\%) appeared to rely on their gym instructors' advice for their intake; a lower proportion (13.0\%) consulted physicians, while none of them consulted nutritionists. A high consumption of milk has been noticed in both users $(67,7 \%)$ and non-users $(52,8 \%)$; supplement non-users consumed significantly more snacks and bakery products than users per week $(P<0.001)$, while users consumed significantly more protein-rich foods $(P<0.01)$ with a particular preference for meat $(48.0 \%)$.

Conclusions: A considerable number of regular strength training adepts consume protein supplements mixed with other products (mainly creatine and amino-acids). Limited numbers consult "dietary specialists" and rely mainly on their instructors. We emphasize on the importance of the dissemination of scientifically based information about supplementation in this environment and the promotion of updated educational programs for the instructors.

\section{Introduction}

Nutrition is traditionally perceived as a crucial component of physical fitness and performance. In the last few decades, the increasing understanding of human nutrition and its effects on the metabolism have led to a wiser management of the intake and the subsequent sport performance.

\footnotetext{
* Correspondence: antonino.bianco@unipa.it

'Department of Sports and Exercise Science (DISMOT), University of Palermo, via Eleonora Duse, 2, 90146, Palermo, Italy

Full list of author information is available at the end of the article
}

Global supplement use in athletes is estimated to range from $40 \%$ to $88 \%$ [1-5], with over 30.000 supplements being commercially-available in the United States (US) [3-5]. More than 3 million people in the US alone are using or have used ergogenic supplements [4-7] believing they may enhance their strength and physical performances. These are also widespread amongst athletes at high school and collegiate levels. However, evidence suggests that supplements might be beneficial only for small subgroups of people [7-11].

\section{() BiolMed Central}


Some authors compared socio-demographic characteristics, like age, gender, education and income, between users and non users of mineral supplements and found significant age-related and education-related differences [12-14]. Other authors showed that intake of various micronutrients from natural foods was higher amongst supplement users compared to non-users; they have also indentified different food preferences between the two groups [15-18].

Supplements are consumed for a variety of reasons. Many exercise active individuals utilize supplements to build muscle, gain strength, prevent future disease or illness and improve performance in sport. Also, studies have shown that people have different opinions about the use of supplements [7-9,18-26]. This finding might be explained by different cultures, type of exercise training and type of dietary supplements. Kaufman et al. [27] found that older persons were more likely to take multivitamin and mineral supplements, while younger persons were more likely to take creatine. The choice of supplements depends also on the reason of the exercise program [20] and/or the type of sport [7]. It has been demonstrated that a significant number of consumers learn about supplements from unqualified sources rather than health professionals [20,21]. One of the aims of this study is to find out if the situation is similar in Palermo, Italy.

Although it is largely known that supplement use is a widespread and accepted practice by athletes and people who attend commercial gyms, with a large range of brands and products in the market $[19,20]$, compared to the US only few studies have been carried out in Europe and other continents in this topic. In particular, we have no references about protein supplement amongst the adepts of strength training in gyms in Italy. Therefore, the purpose of this study was to examine the use of protein supplements, alone or in association with other intakes and also to identify the dietary behavior amongst people who want to "build up muscles" in regular commercial fitness' users in Palermo, Italy.

\section{Methods}

\section{Participants}

Permissions to conduct a survey were obtained from the managers of a representative number of six fitness centers located in the inner city and the suburbs of Palermo in 2009. The fitness centers have been identified using a database of CONI register (National Olympic Committee Register for Sport and Fitness Associations). Using the database of fitness centers, a number of 800 people $(20 \%$ of the total number), have been randomly selected as potential participants.

Only fitness/gym attendees who were taking part in strength training courses have been selected. All gym/fitness users practicing aerobic activities (such as Aerobic,
Spinning, Step, circuit training, endurance and cardiovascular programs, etc...) were excluded. On the basis of these inclusion/exclusion criteria, a total of 207 participants were retained for the investigation.

\section{Questionnaire procedure}

In order to evaluate supplements use, dietary behavior and other related information, a 19-items questionnaire was developed based on previously published studies [20-24]. An informal pilot survey was preliminarily conducted among 27 customers of two fitness centers in order to identify issues of timing, wording or minor clarifications. The pilot-interviewed subjects had similar demographics and educational level to the target population.

The instrument examined the use of dietary supplements and their nutrient content (protein in association with other supplements), dietary behavior, reasons for use, education level and occupation. This latest was categorized as sedentary, standing, manual work and heavy manual work, according to the EPIC physical activity questionnaires criteria [22]. Easy definitions of the supplements were provided to the participants. Completion of the questionnaire implied respondent consent to participate in the study. According to the Italian regulations, ethical approval was not required for this study. The questionnaire was completed using the face-to-face interview method during four months by the same investigator. The surveyed population was split between supplement users and non users for comparison.

\section{Data Analysis}

Data analysis was performed using EpiInfo software version 3.2 (CDC, Atlanta, GA, US) and Statistica version 8.0 software for Windows (Tulsa, OK, US). The descriptive analysis was performed by calculating the means, standard deviations and the frequencies. Differences were assessed by one-way ANOVA test, Kruskall-Wallis, chi-square test or exact test of Fisher when appropriate. The associations between the variables under examination were evaluated using contingency tables. Statistical significance was set at $\mathrm{P}$ values $\leq 0.05$.

\section{Results}

\section{Demographics}

207 questionnaires were collected at the end of the survey period representing 80 females and 127 males. Table 1 summarizes the socio-demographic characteristics of the respondents. The average age of the surveyed subjects was $26.3 \pm 9.1$ yrs. Almost a quarter $(23.7 \%)$ had attended eight years in the primary and secondary education and $21.3 \%$ had graduated from universities ( $\geq 13$ years of education). The majority of the subjects were males (61.4\%) and attended gym for one to five years (47.0\%). Their job type was self categorized as sedentary (12.1\%), requires 
Table 1 Demographic and lifestyle characteristics of participants, Palermo, Italy

\begin{tabular}{|c|c|c|}
\hline & \multicolumn{2}{|c|}{ Subjects } \\
\hline & Number & Percentage \\
\hline \multicolumn{3}{|l|}{$\overline{\text { Age }(y r)}$} \\
\hline$<18$ & 23 & $11.1 \%$ \\
\hline $18-30$ & 136 & $65.7 \%$ \\
\hline$>30$ & 48 & $23.2 \%$ \\
\hline Mean (SD) & \multicolumn{2}{|c|}{$26,3 \pm 9,1 \mathrm{yr}$} \\
\hline \multicolumn{3}{|l|}{ Education (yr) } \\
\hline$\leq 5$ & 2 & $1.0 \%$ \\
\hline 8 & 49 & $23.7 \%$ \\
\hline 13 & 112 & $54.1 \%$ \\
\hline$>13$ & 44 & $21.3 \%$ \\
\hline \multicolumn{3}{|l|}{ Gender † } \\
\hline Female & 80 & $38.6 \%$ \\
\hline Male & 127 & $61.4 \%$ \\
\hline \multicolumn{3}{|l|}{ Body mass index } \\
\hline$<25 \mathrm{~kg} / \mathrm{m}^{2}$ & 149 & $71.9 \%$ \\
\hline $25 \leq 30 \mathrm{~kg} / \mathrm{m}^{2}$ & 51 & $24.6 \%$ \\
\hline$\geq 30 \mathrm{~kg} / \mathrm{m}^{2}$ & 7 & $3.5 \%$ \\
\hline \multicolumn{3}{|l|}{ Activity at work } \\
\hline Heavy manual work & 54 & $26.1 \%$ \\
\hline Manual work & 56 & $27.1 \%$ \\
\hline Standing & 72 & $34.8 \%$ \\
\hline Sedentary & 25 & $12.1 \%$ \\
\hline \multicolumn{3}{|l|}{ Recreational activity } \\
\hline Yes & 93 & $44.9 \%$ \\
\hline No & 114 & $55.1 \%$ \\
\hline
\end{tabular}

standing (34.8\%), manual work (27.1\%) and heavy manual work $(26.1 \%)$. The frequency of their strength training was one to two hours, three to five times per week.

\section{Supplement use}

Participants were asked to acknowledge the type and frequency of use of all the supplements they were consuming at the time of the survey. The majority of the subjects reported they didn't take any dietary supplement (69.9\%). When data were compared by gender, men appeared to be more likely to use protein supplements than women $(34.1 \% \mathrm{v} 23.8 \%$ respectively; $P=$ $0.06)$. The use of supplements was lasting $2.6 \pm 3.3$ years without reaching a significant difference between genders. Preferred types of supplements and protein packaging by frequency of use are described in Table 2. Whey protein shakes $(50.0 \%)$ in association with creatine and amino acids (48.3\%) up to seven times per week $(24.2 \%)$ was the most frequently consumed supplement (Table 2).
Table 2 Frequency and type of supplements used among participants

\begin{tabular}{|c|c|c|}
\hline & \multicolumn{2}{|c|}{ Subjects } \\
\hline & Number & Percentage \\
\hline \multicolumn{3}{|l|}{ Supplements use } \\
\hline No & 145 & $69.9 \%$ \\
\hline Yes & 62 & $30.1 \%$ \\
\hline \multicolumn{3}{|l|}{ Users of supplement by gender } \\
\hline Male & 43 & $34.1 \%$ \\
\hline Female & 19 & $23.8 \%$ \\
\hline \multicolumn{3}{|l|}{ Frequency of use } \\
\hline 1 time per wk & 8 & $12.9 \%$ \\
\hline 2 times per wk & 5 & $8.1 \%$ \\
\hline 3 times per wk & 13 & $21.0 \%$ \\
\hline 4 times per wk & 11 & $17.7 \%$ \\
\hline 5 times per wk & 9 & $14.5 \%$ \\
\hline 6 times per wk & 1 & $1.6 \%$ \\
\hline 7 times per wk & 15 & $24.2 \%$ \\
\hline \multicolumn{3}{|l|}{ Protein supplements } \\
\hline Whey protein shakes & 31 & $50.0 \%$ \\
\hline Egg protein shakes & 15 & $24.1 \%$ \\
\hline Protein bars & 12 & $19.3 \%$ \\
\hline Protein Gel & 1 & $1.6 \%$ \\
\hline Protein shake blends & 3 & $4.8 \%$ \\
\hline \multicolumn{3}{|l|}{ Other supplements* } \\
\hline Multivitamin/mineral & 3 & $4.8 \%$ \\
\hline Creatine - Amino acids & 30 & $48.3 \%$ \\
\hline Amino acids & 16 & $25.9 \%$ \\
\hline Multivitamin/mineral - Creatine - Amino acids & 8 & $12.9 \%$ \\
\hline Multivitamin/mineral - Amino acids & 1 & $1.6 \%$ \\
\hline Creatine & 4 & $6.4 \%$ \\
\hline
\end{tabular}

*Other supplements in association with protein supplements.

\section{Source of information about use of supplements}

When examining the source of information, a majority of the subjects $(34.0 \%)$ appeared to rely on the gym instructors' guideline/advice, on the Internet (18.0\%) or on "word to mouth" (16.0\%). Only $13.0 \%$ of the participants consulted a physician, the shopkeepers at the stores were considered as a source of information by $5.0 \%$. Unexpectedly, $14.0 \%$ of the participants used books or magazines as a source of information (Figure 1). Amongst the users, no one has consulted a nutritionist for advice on supplements.

\section{Dietary behavior}

The survey showed that all groups consume milk more than three days per week [67\% of the supplement users vs $52 \%$ in the non users ( $p>0.05)$ ]. However, the nonusers consumed significantly more snacks and bakery 


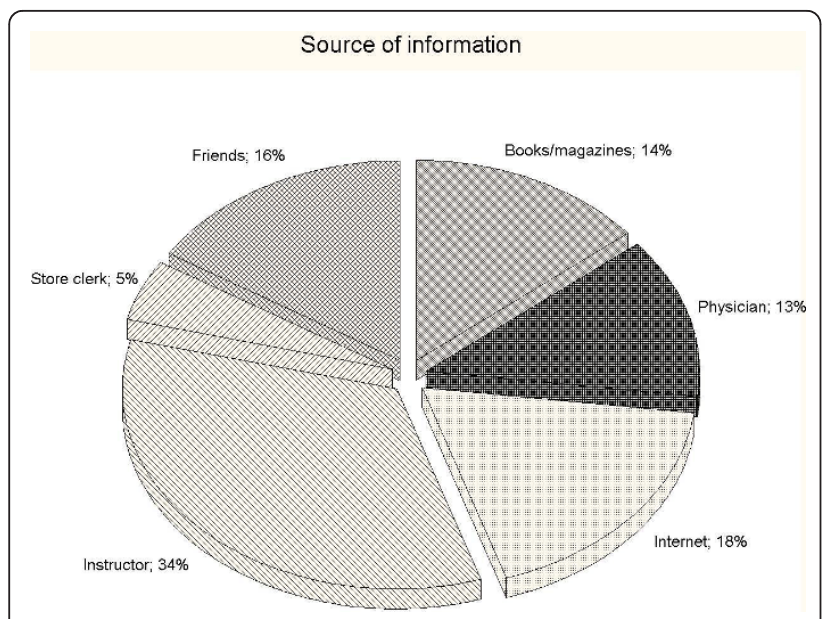

Figure 1 Source of information about use of supplements. Distribution of source of information amongst users.

products than the users per week $(P<0.001)$. On the contrary, supplement users consumed significantly more nuts, tuna, eggs, fish, legumes, meat, milk and yogurt than non-users $(P<0.01)$. The favorite high protein food of the both groups was meat (48.0\%) (Figure 2).

\section{Discussion}

Morrison et al. [20] compared supplement use by age group and found that young people consumed protein shakes/bars and creatine more than older people in the US. Other studies confirmed that the type of supplements used is age-related besides the type of exercise training [27-30]. Moreover, in Brazil, Goston and Correia [30] found that use of supplements was associated with the people who needed them less, since their diet appeared concurrently to be good or excellent. A similar observation has been described by Conner et al. [31] and Millen et al. [32]. Many authors suggest that athletes need extra protein in their diet as food or as supplements [33-37], however regular gym attendees do not need these extra supplements [30,34,37]. When comparing protein supplements by age and strength exercise training groups between our data and others from different studies, it appears that US has the highest prevalence of users with 59.8\% among 85 subjects [20] followed by Brazil with $40.1 \%$ of users among 231 subjects [30]. Our survey showed $30.1 \%$ of supplement users amongst 207 subjects [Table 2]. According to other investigations, our study shows supplement consumption is more prevalent amongst men attending gyms [7,20,30]. Moreover, after stratifying protein supplements in whey protein shakes, egg protein shakes, protein bars, protein gel and protein shake blends, it appears that a majority of the users were taking whey protein shakes $(50.0 \%)$, probably because they are thought to be the most effective. The questions that remain unanswered are: are they really more effective or rather more promoted by the media? And are they cheaper than others?

Our investigation also showed that younger supplement users did not habitually add multivitamin or minerals to their protein supplements. This finding is in accordance with previous studies [20,30].

In terms of source of information, we found that a high proportion of the subjects $(34.0 \%)$ relied on the instructor. This was slightly lower than the rate found by Morrison et al. [20] amongst the American sample (38.7\%), while Goston and Correia [30] reported only $14.1 \%$ of the users in Brazil relying on the gym instructors' guidelines. In this study, only few persons indicated consulting a physician for supplementation prescription (13.0\%), a similar rate was reported by Goston and Correia [30] (14.6\%), however, those rates were quite different to that reported by Morrison et al. [20]. In our sample of Italian fitness centers users, "word to mouth" was found to

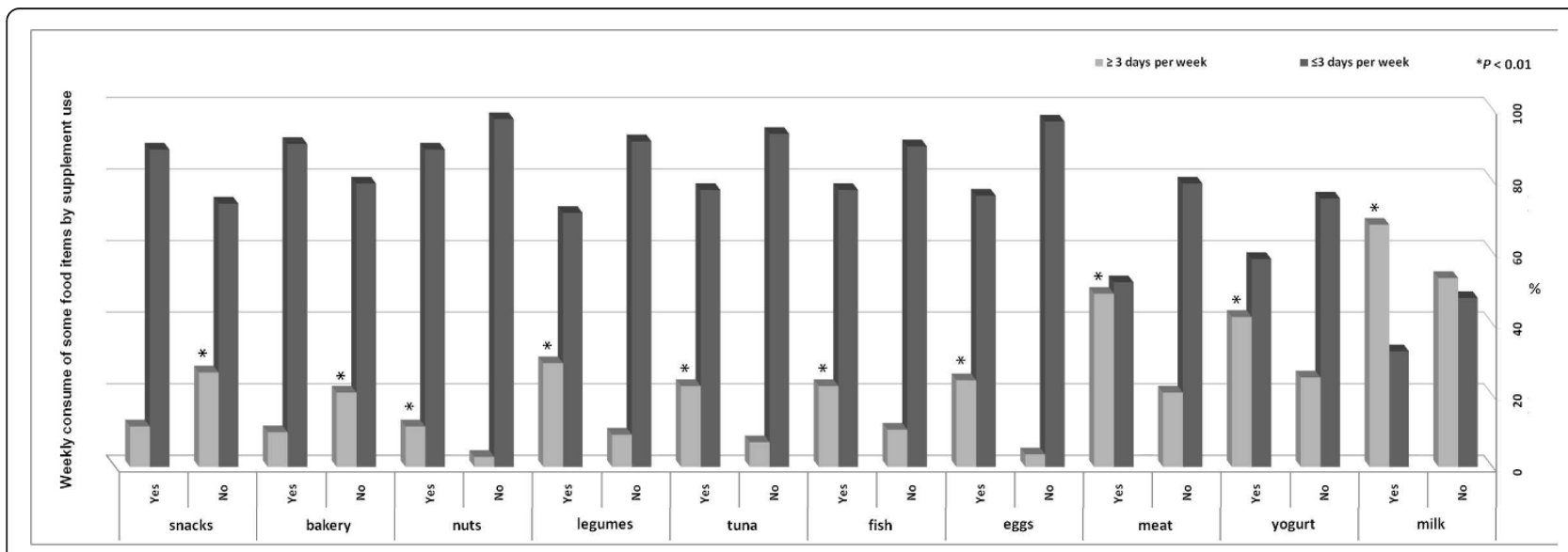

Figure 2 Weekly consumption of some food items. Weekly consumption of some food items by users (Yes) compared with non users (No), reported in $\geq 3$ days per week and $\leq 3$ days per week. 
represent $16.0 \%$ of the information sources of supplementation, whilst Goston and Correia [30] reported 9.9\% and Morrison et al. [20] 63.1\%. It is important to underline that no one indicated consulting a nutritionist, whereas in Morrison et al' [20] and Goston and Correia' studies [30] the relative proportion is as high as $30.0 \%$. It is clear that more studies are necessary to better understand this phenomenon.

In agreement with Goston and Correia [30], we found that users consumed more high protein food than nonusers, in particular meat, but less snacks and bakery products than non-users. In addition, the use of supplements appears to be associated with persons who have already healthier dietary habits [38]. The sample size could be considered a limit of the study but considering strength and conditioning adepts only, most of the studies we found reported similar sample size $[20,30]$. This might be related to the difficulties to deal with managers and fitness adepts. In order to overcome these difficulties and to increase the sample a project named PP (Protein Project) is currently involving three European universities and the Italian National Olympic Committee (CONI). The results of this study will hopefully be published in future manuscripts and complete the current investigation.

\section{Conclusion}

The percentage of supplement users was significantly lower in our study compared to others maybe because there is less marketing by protein supplement companies. This investigation showed a considerable number of adepts consumed protein dietary supplements in association with other high protein food. Whey protein shakes (50.0\%) mixed with creatine and amino-acids (48.3\%) were the most frequent choices amongst the users. The majority wasn't aware of the implications and the secondary effects of the supplements, since they were passively following their instructor's suggestions, got information from the Internet or from a friend. Only few obtained advice from a physician and none from a nutritionist.

As previously showed, we concluded that gym adept supplement users were not aware of objective recommendations for protein intake and may perceived their needs to be excessively high. It is generally accepted that athletes have increased protein needs. The position statement of the International Society of Sports Nutrition states that exercising individuals' protein needs are between 1.4 and $2.0 \mathrm{~g} / \mathrm{kg} /$ day, depending upon mode and intensity of exercise, quality of protein, and status of total calorie and carbohydrate intake. General population attending commercial gyms usually had less workload than athletes, so daily protein intake should be in line with athletes guidelines or less.

Also, in agreement with previous studies, we think that it is extremely important to disseminate accurate information on the supplementation products mainly in the fitness centers. The promotion of updated educational programs and the integration of nutrition courses within the instructors' training will certainly help gym users achieving their objectives while guaranteeing less primary and secondary health risks.

\section{Acknowledgements}

This study was supported in part by CONI (National Olympic Committee; Comitato Provinciale di Palermo). We are grateful to Dr. Calogero Carrubba for his invaluable support.

We also want to thank all participants and the fitness/gym centers managers.

\section{Author details}

'Department of Sports and Exercise Science (DISMOT), University of Palermo, via Eleonora Duse, 2, 90146, Palermo, Italy. ${ }^{2}$ Department of Sciences for Health Promotion "G. D'Alessandro", University of Palermo, Palermo, Italy. ${ }^{3}$ Department of Anatomy and Physiology "Human Physiology section", University of Padua, Italy. ${ }^{4}$ Regional School of Sport, CONI Sicilia, Italy. ${ }^{5}$ Department of life and sport science, University of Greenwich, UK.

\section{Authors' contributions}

All authors have effectively contributed to this work in its different production stages. All authors read and approved the final manuscript.

\section{Competing interests}

The authors declare that they have no competing interests.

Received: 15 July 2011 Accepted: 29 December 2011 Published: 29 December 2011

\section{References}

1. Silver MD: Use of ergogenic aids by athletes. J Am Acad Orthopaed Surg 2001, 9:61-70.

2. Williams MH: Nutrition for health, fitness \& sports, 7/e McGraw-Hill. New York: 2008

3. Tekin KA, Kravitz $L$ : The growing trend of ergogenic drugs and supplements. ACSM'S Health Fitness J 2004, 8:15-18.

4. Palmer ME, Haller C, McKinney PE, Klein-Schwartz W, Tschirgi A, Smolinske SC, Woolf A, Sprague BM, Ko R, Everson G, Nelson LS, DoddButera T, Bartlett WD, Landzberg BR: Adverse events associated with dietary supplements: an observational study. Lancet 2003, 361:101-106.

5. Krumbach CJ, Ellis DR, Driskell JA: A report of vitamin and mineral supplement use among university athletes in a Division I institution. Int J Sport Nutr 1999, 9:416-25.

6. Froiland K, Koszewski W, Hingst J, Kopecky L: Nutritional supplement use among college athletes and their sources of information. Int J Sport Nutr Exerc Metab 2004, 14:104-20.

7. Scofield DE, Unruh S: Dietary supplement use among adolescent athletes in central Nebraska and their sources of information. J Strength Cond Res 2006, 20(2):452-5.

8. Applegate E: Effective nutritional ergogenic aids. Int J Sports Nutr 1999 9:229-239

9. Dodge J: From Ephedra to creatine: Using theory to respond to dietary supplement use in young athletes. Am J Health Stud 2003, 18(2 \& 3):111-116.

10. Froiland K, Koszewski W, Hingst J, Kopecky L: Nutritional supplement use among college athletes and their sources of information. Int J Sport Nutr Exerc Metab 2004, 14:104-120.

11. Perko M: Development of a theory-based instrument regarding adolescent athletes and dietary supplements. Am J Health Stud 1999, 15(2):71-80.

12. Balluz LS, Kieszak SM, Philen RM, Mulinare J: Vitamin and mineral supplement use in the United States. Results from the Third National Health and Nutrition Examination Survey. Arch Fam Med 2000, 9:258-262.

13. Wallström $P$, Elmståhl $S$, Hanson BS, Östergren $P$, Johansson $U$, Janzon L, Larsson SA: Demographic and psychosocial characteristics of middle- 
aged women and men who use dietary supplements. Results from the Malmödiet and cancer study. Eur J Publ Health 1996, 6:188-195.

14. Greger JL: Dietary supplement use: Consumer characteristics and interests. J Nutr 2001, 131(Suppl 4):S1339-S1343.

15. Beitz R, Mensink GBM, Fischer B, Thamm M: Vitamins - Dietary intake and intake from dietary supplements in Germany. Eur J Clin Nutr 2002, 56:539-545.

16. Slesinski MJ, Subar AF, Kahle LL: Dietary intake of fat, fiber and other nutrients is related to the use of vitamin and mineral supplements in the United States: The 1992 National Health Interview Survey. J Nutr 1996, 126:3001-3008

17. Block G, Cox C, Madans J, Schreiber GB, Licitra L, Melia N: Vitamin supplement use, by demographic characteristics. Am J Epidemiol 1998, 127:297-309.

18. Lyle BJ, Mares-Perlman JA, Klein BEK, Klein R, Greger JL: Supplement users differ from nonusers in demographic, lifestyle, dietary and health characteristics. J Nutr 1998, 128:2355-2362.

19. Molinero O, Márquez S: Use of nutritional supplements in sports: risks, knowledge, and behavioural-related factors. Nutr Hosp 2009, 24(2):128-34.

20. Morrison LJ, Gizis F, Shorter B: Prevalent use of dietary supplements among people who exercise at a commercial gym. Int I Sport Nutr Exerc Metab 2004, 14(4):481-92.

21. Eliason BC, Kruger J, Mark D, Rasmann DN: Dietary supplement users: demographics, product use, and medical system interaction. J Am Board Fam Prac 1997, 10:265-271.

22. Cust AE, Smith BJ, Chau J, van der Ploeg HP, Friedenreich CM, Armstrong BK, Bauman A: Validity and repeatability of the EPIC physical activity questionnaire: a validation study using accelerometers as an objective measure. Int I Behav Nutr Phys Act 2008, 5:33.

23. Eldridge AL, Sheehan ET: Food supplement use and related beliefs: survey of community college students. J Nutr Educ 1994, 26:259-265.

24. Rauch HGL, Hawley JA, Woodey M, Noakes TD, Dennis SC: Effects of ingesting a sports bar versus glucose polymer on substrate utilization and ultra-endurance performance. Int J Sports Med 1999, 20:252-257.

25. Braun H, Koehler K, Geyer H, Kleinert J, Mester J, Schänzer W: Dietary supplement use among elite young german athletes. Int I Sport Nutr Exerc Metab 2009, 19:97-109.

26. Erdman KA, Fung TS, Doyle-Baker PK, Verhoef MJ, Reimer RA: Dietary supplementation of high-performance Canadian athletes by age gender. Clin J Sport Med 2007, 17:458-64.

27. Kaufman DW, Kelly JP, Rosenberg L, Anderson TE, Mitchell AA: Recent patterns of medication use in the ambulatory adult population of the United States: The Slone Survey. JAMA 2002, 287:337-344.

28. Neuhouser ML, Patterson RE, Levy L: Motivations for using vitamin and mineral supplements. J Am Diet Assoc 1999, 99:851-854.

29. Francaux M, Demeure R, Goudemant JF, Poortmans JR: Effect of exogenous creatine supplementation on muscle $\mathrm{PCr}$ metabolism. Int J Sports Med 2000, 21:139-145.

30. Goston $\mathrm{JL}$, Correia MI: Intake of nutritional supplements among people exercising in gyms and influencing factors. Nutrition 2010, 26:604-611.

31. Conner M, Kirk SF, Cade KE, Barret JH: Environmental influences: factors influencing a woman's decision to use dietary supplements. J Nutr 2003, 133:19785-82S.

32. Millen AE, Dodd KW, Subar AF: Use of vitamin, mineral, nonvitamin, and nonmineral supplements in the United States: the 1987, 1992, and 2000 National Health Interview Survey results. J Am Diet Assoc 2004, 104:942-50

33. Maughan RJ, King DS, Trevor L: Dietary supplements. J Sports Sci 2004, 22:95-113.

34. Campbell B, Kreider RB, Ziegenfuss T, La Bounty P, Roberts M, Burke D, Landis J, Lopez H, Antonio J: International Society of Sports Nutrition position stand: protein and exercise. J Int Soc Sports Nutr 2007, 4:8.

35. Williams MH: Dietary supplements and sports performance: amino acids. J Int Soc Sports Nutr 2005, 2:63-7.

36. Nemet $D$, Wolach $B$, Eliakim A: Proteins and amino acid supplementation in sports: are they truly necessary? Isr Med Assoc J 2005, 7:328-32.

37. Fox EA, McDaniel JL, Breitbach AP, Weiss EP: Perceived protein needs and measured protein intake in collegiate male athletes: an observational study. J Int Soc Sports Nutr 2011, 8:9.
38. International Olympic Committee (IOC) consensus statement on sports nutrition 2010. [http://www.olympic.org/Documents/Reports/EN/ CONSENSUS-FINAL-v8-en.pdf].

doi:10.1186/1550-2783-8-25

Cite this article as: Bianco et al:: Protein supplementation in strength and conditioning adepts: knowledge, dietary behavior and practice in Palermo, Italy. Journal of the International Society of Sports Nutrition 2011 8:25.

\section{Submit your next manuscript to BioMed Central and take full advantage of:}

- Convenient online submission

- Thorough peer review

- No space constraints or color figure charges

- Immediate publication on acceptance

- Inclusion in PubMed, CAS, Scopus and Google Scholar

- Research which is freely available for redistribution 